\title{
Keterkaitan Aktivitas Manusia dengan Kualitas Ekosistem Perairan Pantai di Kepulauan Spermonde, Makassar, Sulawesi Selatan
}

\author{
Catur Retnaningdyah ${ }^{1 *}$, Luchman Hakim ${ }^{1)}$, Arina Mana Sikana ${ }^{2)}$, Rispah Hamzah' ${ }^{2)}$ \\ 1) Jurusan Biologi Fakultas MIPA, Universitas Brawijaya \\ 2) Mahasiswa Magister Biologi Fakultas MIPA, Universitas Brawijaya \\ *) Alamat korespondensi: catur@ub.ac.id
}

\begin{abstract}
ABSTRAK
Kepulauan Spermonde, Makassar Sulawesi Selatan terdiri dari ratusan pulau kecil dengan karakteristik yang bervariasi. Tujuan dari penelitian ini adalah untuk menganalisis hubungan antara kondisi lingkungan dan aktivitas manusia di pulau dengan kualitas ekosistem perairan pantai berdasarkan parameter fisika-kimia air serta keragaman biodiversitas khususnya Makroalga dan Echinodermata. Penelitian ex post facto ini dilakukan di Pulau Barrangcaddi, Badi, Barang Lompo, Bonebatang dan Pulau Kodingarengkeke. Pemantauan kondisi lingkungan menggunakan indeks Naturalness sedangkan aktivitas manusia menggunakan indeks Hemeroby. Pengambilan sampel air, Makroalga, dan Echinodermata di setiap pulau dilakukan di dua hingga tiga stasiun dengan membuat tiga (3) transek sabuk. Hasil analisis pemodelan persamaan struktural menggunakan WarpPLS (Partial Least Square) menunjukkan bahwa aktivitas manusia yang ada di Kepulauan Spermonde telah berdampak pada pencemaran bahan organik dengan kadar Biochemical Oxygen Demand (BOD) berkisar 25,39-29,81 mg/L. Pencemaran ini selanjutnya telah memicu terjadinya eutrofikasi perairan tercermin dari kadar nitrat yang telah melebihi baku mutu untuk biota perairan $(0,05-0,168 \mathrm{mg} / \mathrm{L})$. Eutrofikasi yang terjadi telah meningkatkan diversitas Makroalga dan selanjutnya menurunkan diversitas Echinodermata. Nilai indeks diversitas Makroalga perairan pantai di sekitar lima pulau yang diamati termasuk dalam kategori rendah sampai sedang $(1,17-2,42)$. Nilai indeks diversitas Echinodermata termasuk kategori rendah $(0,36-0,88)$. Parameter kualitas air lain terutama pH, suhu, salinitas, kekeruhan, total fosfat (TP), $\mathrm{H}_{2} \mathrm{~S}$, minyak dan lemak, dan timbal $(\mathrm{Pb})$ telah memenuhi standar kualitas air untuk kebutuhan biota perairan berdasarkan Keputusan Menteri Lingkungan Hidup Indonesia No. 51/2004.
\end{abstract}

Kata kunci: Echinodermata, Kepulauan Spermonde, Makroalga, model persamaan struktural

\section{The Relationship between Human Activities with the Quality of Coastal Waters Ecosystem in the Spermonde Archipelago, Makassar, South Sulawesi}

\author{
Catur Retnaningdyah" ${ }^{1 *}$, Luchman Hakim ${ }^{1}$, Arina Mana Sikana ${ }^{2)}$, Rispah Hamzah ${ }^{2)}$ \\ 1) Biology Department, Faculty of Mathematic and Natural Sciences, Universitas Brawijaya \\ 2) Master student, Faculty of Mathematic and Natural Sciences, Universitas Brawijaya \\ *) Email: catur@ub.ac.id
}

\begin{abstract}
Spermonde archipelago, Makassar South Sulawesi consists of hundreds of small islands with varying characteristics. The purpose of this study is to analyze the relationship between environmental conditions and human activities on the island with the quality of coastal waters ecosystems based on water physics-chemical parameters and biodiversity diversity, especially Macroalgae and Echinoderms. This ex post facto research was carried out in Barrangcaddi Island, Badi, Barang Lompo, Bonebatang and Kodingarengkeke Islands. Monitoring environmental conditions uses the Naturalness index while human activity uses the Hemeroby index. Water, Macroalgae and Echinoderms sampling on each island was carried out at two to three stations by making three (3) belt transects. The result of structural equation modeling analysis using WarpPLS showed that human activity in the Spermonde Islands had an impact on organic matter pollution with BOD levels ranging from 25.39 to $29.81 \mathrm{mg} / \mathrm{L}$. This pollution has further triggered water eutrophication as reflected by nitrate levels which have exceeded the quality standard for aquatic biota $(0.05-0.168 \mathrm{mg} / \mathrm{L})$. This eutrophication then increased the diversity of Macroalgae and subsequently reduced the diversity of Echinoderms. The diversity index value of Macroalgae in the coastal waters around of the five islands be observed were included in the low to moderate category (1.17-2.42). The diversity index value of Echinoderms was low (0.36-0.88). While other water quality parameters, especially $\mathrm{pH}$, temperature, salinity, turbidity, total phosphate, $\mathrm{H}_{2} \mathrm{~S}$, oil and
\end{abstract}


fat, and $\mathrm{Pb}$ had met the water quality standards for the needs of aquatic biota based on the Decree of Indonesia Minister of Environment No. 51/2004.

Keywords: Echinoderms, Spermonde Islands, Macroalgae, structural equation modeling

\section{PENDAHULUAN}

Kepulauan Spermonde, Makassar Sulawesi Selatan terdiri dari ratusan pulau kecil dengan kondisi lingkungan dan aktivitas manusia yang bervariasi. Pulau-pulau tersebut ada yang berpenduduk dan ada juga yang tidak. Ketersediaan air tawar merupakan salah satu hal utama yang menyebabkan masyarakat pulau memilih untuk menetap di pulau tertentu [1]. Pengembangan daerah pesisir dan pulau-pulau di Makassar saat ini ditujukan untuk pariwisata [2]. Selain itu, fungsi lain pesisir ini adalah untuk pelabuhan kapal Pelni, kapal Tradisional antar pulau, perikanan, dan jalur transportasi laut. Berbagai aktivitas tersebut akan berdampak pada penurunan kualitas ekosistem perairan pantai di antaranya peningkatan kadar limbah toksik dan juga nutrien di perairan yang selanjutnya akan terjadi eutrofikasi [3] [4]. Hal ini selanjutnya akan memicu peningkatan biomassa produsen seperti Makroalga yang berakibat pada kondisi anoksik di perairan bawah dan sedimen, sehingga dapat mengancam kehidupan biota laut lain seperti Echinodermata.

Pengendalian pencemaran perairan pantai perlu dilakukan sesuai dengan peraturan yang telah ditetapkan dalam Keputusan Menteri Negara Lingkungan Hidup Nomor: 51 Tahun 2004 melalui upaya pendugaan kualitas air metode fisika-kimia dan biologi. Namun sejauh itu masih sedikit penelitian yang dilakukan di Indonesia berkaitan dengan pemakaian biota laut sebagai penunjuk kualitas ekosistem perairan pantai. Komunitas organisme perairan seperti Makroalga dan Echinodermata dapat digunakan sebagai indikator tingkat kesehatan suatu ekosistem perairan $[5,6,7,8,9]$. Hal ini disebabkan interaksi antara biota air dengan habitatnya, pada hakikatnya merupakan keseimbangan dinamis, sehingga setiap perubahan lingkungan habitat yang disebabkan masuknya zat pencemar ke dalam air, akan berpengaruh terhadap kehidupan dan komposisi biota.
Berdasarkan latar belakang di atas, maka tujuan penelitian ini adalah melakukan analisis keterkaitan/hubungan antara kondisi lingkungan dan aktivitas manusia di lima pulau yang ada Kepulauan Spermonde Makassar Sulawesi Selatan dengan kualitas ekosistem perairan pantai berdasarkan parameter fisikakimia air serta keragaman biodiversitas khususnya Makroalga dan Echinodermata. Hasil penelitian ini selanjutnya diharapkan dapat digunakan sebagai dasar pengelolaan dan pengembangan bidang teknologi perlindungan lingkungan.

\section{METODE PENELITIAN}

Penelitian dengan metode ex post facto ini dilakukan di ekosistem perairan pantai lima pulau yaitu Pulau Barrangcaddi, Badi, Barang Lompo, Bonebatang dan Pulau Kodingarengkeke Kepulauan Spermonde Makassar Sulawesi Selatan (Gambar 1). Variabel terikat dalam penelitian ini adalah parameter fisika-kimia kualitas air, struktur komunitas Makroalga, dan Echinodermata, sedangkan variabel bebas adalah kondisi lingkungan dan atau aktivitas manusia di sekitar ekosistem perairan pantai. Pengambilan sampel pada tiap-tiap pulau dilakukan pada dua sampai dengan tiga stasiun yaitu ekosistem perairan pantai yang mempunyai variasi kualitas lingkungan diakibatkan oleh variasi aktivitas manusia di sekitarnya. Pengambilan sampel pada tiap-tiap stasiun tersebut dilakukan dengan membuat tiga belt transect yang ditentukan secara acak sebagai ulangan.

Parameter kualitas fisika-kimia air yang diukur adalah $\mathrm{pH}$, DO, suhu, salinitas, turbiditas, BOD, nitrat, TP, $\mathrm{H}_{2} \mathrm{~S}$, minyak dan lemak, serta $\mathrm{Pb}$. Selain itu juga, pengamatan faktor lingkungan dilakukan meliputi kondisi pemanfaatan lahan di wilayah penelitian serta aktivitas manusia menggunakan indeks Naturalness dan Hemeroby. Pengamatan terhadap struktur komunitas dan diversitas Makroalga dan Echinodermata (taxa richness, 

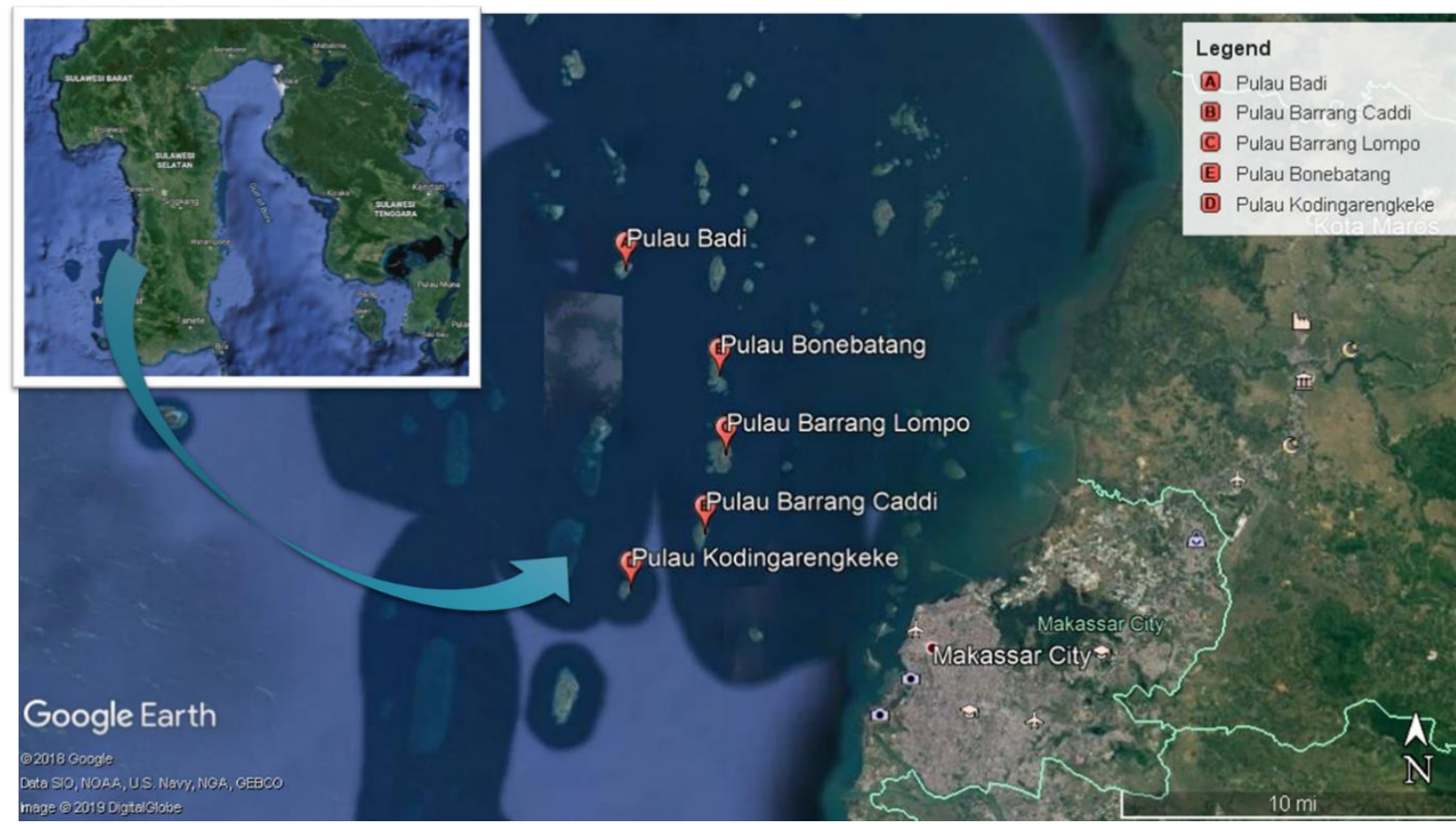

(P) Pulau Bonebatang

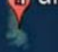

CPulau Barrang Lompo

(Pulau Barrang Caddi

CPulau Kodingarengkeke
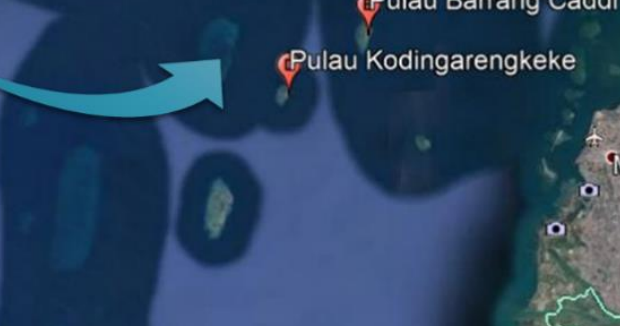

Gambar 1. Lokasi pengambilan sampel penelitian

kerapatan total, indeks dominansi, indeks keseragaman, dan indeks diversitas) dilakukan di lokasi yang sama dengan tempat pengambilan sampel air. Pengelompokan kualitas ekosistem tiap pulau dianalisis menggunakan analisis biplot.

Data hasil pemantauan, selanjutnya, digunakan sebagai dasar untuk membuat model keterkaitan antara kondisi pemanfaatan lahan dan aktivitas manusia di lokasi penelitian dengan kualitas air dan kualitas biodiversitas (Echinodermata dan Makroalga) dalam bentuk pemodelan persamaan struktural yang dianalisis menggunakan WarpPLS.

\section{HASIL DAN PEMBAHASAN}

Hasil analisis Biplot (Gambar 2) menunjukkan bahwa Pulau Badi yang mempunyai kualitas lingkungan alami lebih baik (tercermin dari indeks Naturalness tertinggi) dicirikan oleh kadar DO, salinitas, $\mathrm{pH}$ dan suhu air tinggi dengan kadar nitrat yang sedang. Kualitas lingkungan yang baik ini mampu mendukung struktur komunitas Makroalga yang lebih baik (taxa richness, kelimpahan total dan indeks diversitas yang tinggi) meskipun keragaman Echinodermata termasuk rendah.

Pulau Bonebatang, Barangcaddi dan Kodingarengkeke mempunyai kualitas lingkungan (indeks Naturalness) sedang dengan nilai semua parameter fisika, kimia dan biologi yang sedang. Indeks Naturalness terendah ditemukan di Pulau Baranglompo diakibatkan oleh aktivitas manusia yang tinggi. Hal ini telah berdampak pada degradasi kualitas lingkungan yang diindikasikan kadar nitrat tinggi dan taxa richness, kelimpahan total dan indeks diversitas dari Makroalga rendah, sedangkan keragaman Echinodermata sedang.

Hasil pemantauan kualitas fisika-kimia air menunjukkan bahwa beberapa parameter kualitas air yang diamati di perairan sekitar lima pulau yang ada di Kepulauan Spermonde belum memenuhi standar baku mutu air untuk keperluan kehidupan biota air berdasarkan Keputusan Menteri Negara Lingkungan Hidup No. 51/2004, yaitu (1) kadar DO di pantai sekitar Pulau Bonebatang, Barangcaddi dan Pulau Kodingarengkeke yang mempunyai nilai antara 4,63-4,95 mg/L, (2) kadar BOD di perairan semua pantai yang diamati dengan kisaran nilai 25,39-29,81 mg/L dan (3) kadar nitrat perairan semua pantai dengan nilai berkisar antara 0,03-0,17 mg/L.

Kadar DO yang rendah akan memengaruhi aktivitas respirasi organisme perairan. Setiap organisme mempunyai kisaran toleransi tertentu terhadap kadar oksigen di perairan. Makroalga di perairan pantai lebih toleran terhadap kadar oksigen yang rendah (2-4 mg/L) dibandingkan dengan Coral [10]. Kadar BOD perairan pantai lima pulau yang diamati 


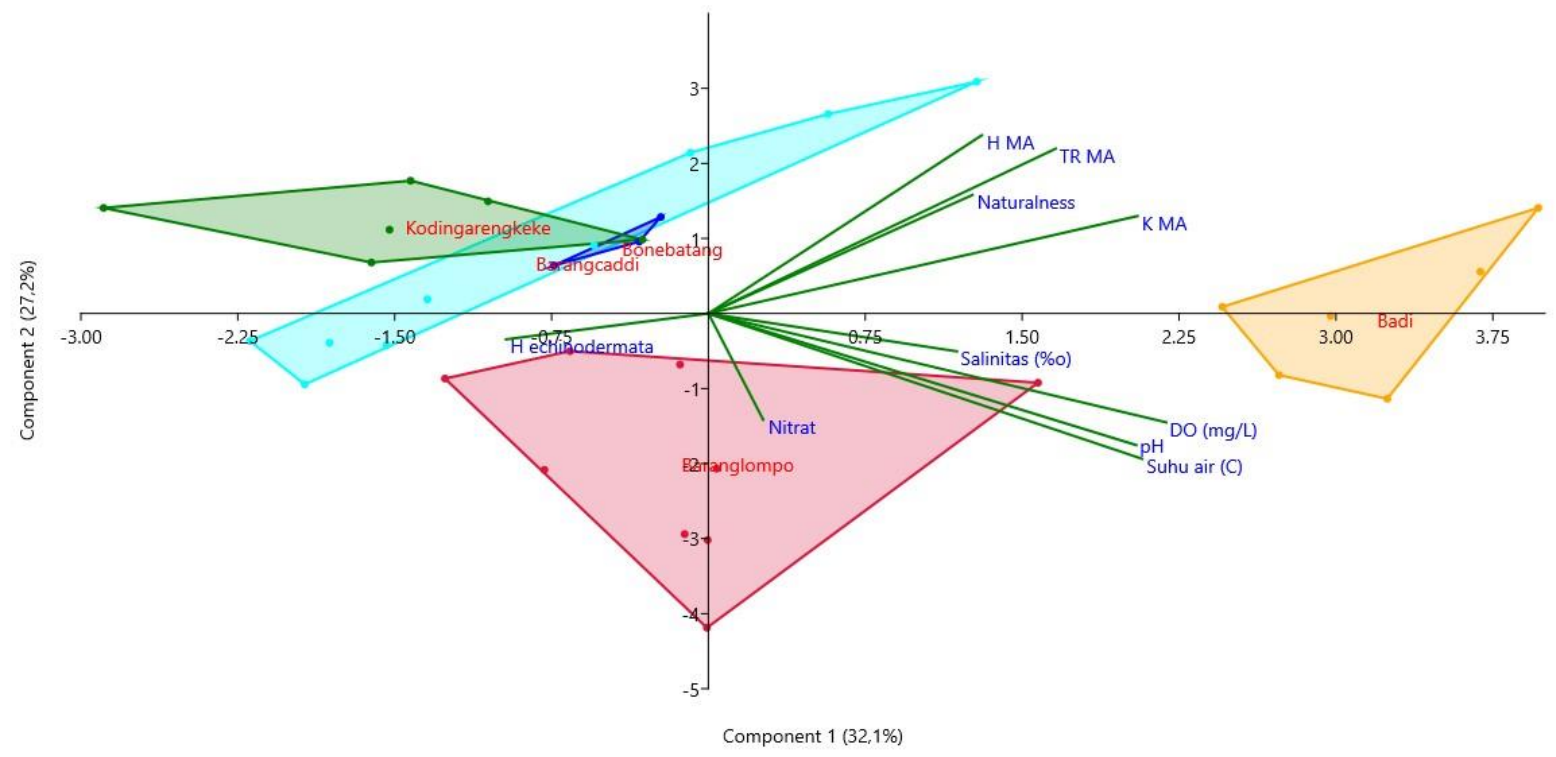

Gambar 2. Pengelompokan ekosistem pantai di Kepulauan Spermonde berdasarkan perbedaan kualitas fisika, kimia, biologi dan indeks Naturalness

termasuk tinggi dan melebihi nilai baku mutu yang ditetapkan untuk biota laut yaitu $20 \mathrm{mg} / \mathrm{L}$. Kadar yang tinggi dari BOD mengindikasikan pencemaran organik di perairan. Pencemaran bahan organik ini selanjutnya akan memengaruhi perubahan struktur komunitas organisme perairan. Hanya jenis organisme yang toleran pada pencemaran bahan organik ini yang akan hidup [11]. Kadar yang tinggi dari BOD ini menunjukkan bahwa perairan pantai di sekitar Kepulauan Spermonde telah terpengaruh oleh aktivitas manusia yang menghuni tiap-tiap pulau tersebut.

Pulau Barangcaddi, Baranglompo dan Badi secara umum dihuni oleh masyarakat yang mempunyai aktivitas sehari-hari untuk keperluan domestik, peternakan dan pertanian. Kebanyakan penduduk yang menempati daerah dekat pantai secara langsung membuang fesesnya ke pantai. Hal ini akan berakibat peningkatan bahan organik di perairan yang ditunjukkan oleh nilai BOD yang tinggi di air. Sedangkan Pulau Kodingarengkeke adalah pulau kecil yang biasanya digunakan untuk aktivitas wisata. Sudah ada satu bangunan di sana dengan kerapatan vegetasi sedikit. Pulau Bonebatang merupakan pulau yang tidak berpenghuni oleh karena saat ini telah tenggelam sehingga semua daratan tertutup oleh air. Kemungkinan kadar BOD tinggi di perairan ini disebabkan oleh aktivitas penduduk yang mengambil galian pasir di pulau ini.
Kadar nitrat berkisar antara 0,05-0,168 $\mathrm{mg} / \mathrm{L}$. Baku mutu kadar nitrat untuk kehidupan biota laut maksimum adalah 0,008 mg/L. Dengan demikian, di semua perairan yang diamati sudah melebih nilai baku mutu yang ditetapkan. Hasil ini mendukung kadar bahan organik yang juga tinggi. Kadar nitrat ini sangat dipengaruhi oleh aktivitas manusia di sekitar perairan. Kadar nitrat yang tinggi akan dapat memicu terjadinya eutrofikasi yang selanjutnya akan mengakibatkan terjadinya blooming algae [12].

Hasil pemantauan nilai $\mathrm{pH}$, suhu, salinitas, turbiditas, kadar total fosfat, minyak dan lemak, sulfida $\left(\mathrm{H}_{2} \mathrm{~S}\right)$ dan timbal $(\mathrm{Pb})$ menunjukkan telah memenuhi nilai baku mutu yang ditetapkan untuk semua lokasi penelitian (suhu air $30,5-33,1^{\circ} \mathrm{C}$; pH 7,99-8,38; salinitas $29,3-$ $30,2 \%$; turbiditas 0,63-1,26 NTU; kadar total fosfat $<0,01$; minyak dan lemak $<0,1$; sulfida $<0,01$; timbal <0,005). Berdasarkan indeks Naturalness, Pulau Bonebatang dan Badi mempunyai kualitas lingkungan alami yang lebih baik (nilai indeks 5), Pulau Barangcaddi dan Kodingarengkeke mempunyai kualitas lingkungan yang sedang (nilai indeks 4) dan kualitas lingkungan di Pulau Baranglompo paling rendah (nilai indeks 3). Hal ini diakibatkan oleh variasi aktivitas manusia di tiap pulau tersebut. Aktivitas manusia di Baranglompo sangat tinggi tercermin dari nilai indeks Hemeroby yang tinggi yaitu 5 sehingga 


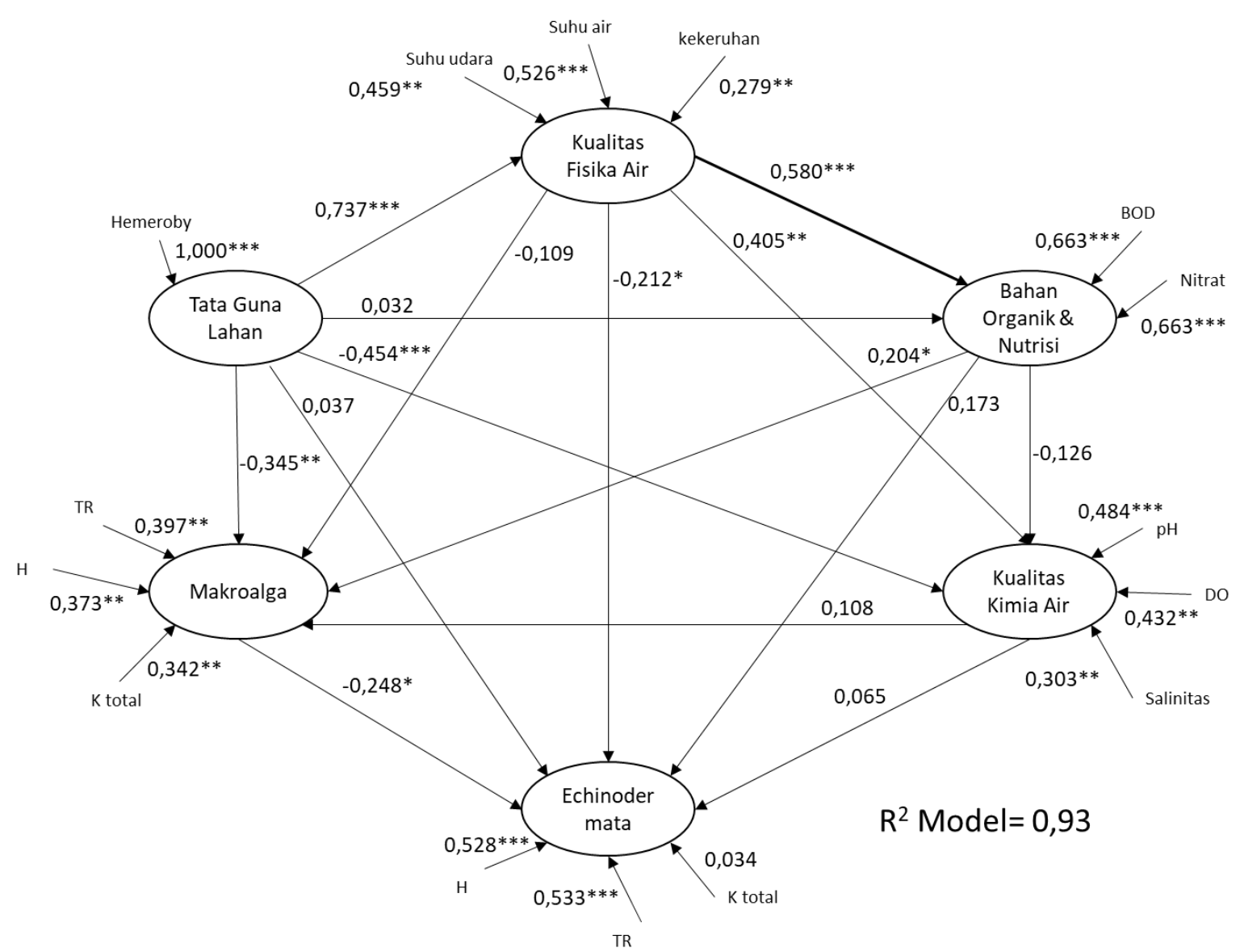

Gambar 3. Interaksi tata guna lahan (aktivitas manusia) dengan kualitas fisika, kimia dan biologi air serta struktur komunitas Makroalga dan Echinodermata

berdampak pada rendahnya kualitas lingkungan alami tercermin dari nilai indeks Naturalness paling rendah.

Hasil analisis pemodelan persamaan struktural menggunakan WarpPLS (Gambar 3) menunjukkan bahwa tata guna lahan dan aktivitas manusia secara signifikan meningkatkan tingkat kekeruhan air serta menurunkan kualitas kimia air dan Makroalga. Pencemaran bahan organik dan eutrofikasi secara signifikan berakibat pada peningkatan Makroalga.

Peningkatan kelimpahan Makroalga dan tingkat kekeruhan berdampak secara signifikan terhadap penurunan kelimpahan Echinodermata yang diduga akibat adanya kompetisi antara kedua komunitas tersebut.

Pertumbuhan populasi Makroalga di perairan sangat tergantung pada berbagai macam senyawa anorganik baik sebagai nutrien makro (N, P, K, Na, Si dan Ca), maupun nutrien mikro (Fe, $\mathrm{Zn}, \mathrm{Mn}, \mathrm{Cu}, \mathrm{Mg}, \mathrm{Mo}, \mathrm{Co}, \mathrm{B})$ [13].
Jumlah total kekayaan taksa Makroalga yang ditemukan sebanyak 16 jenis. Pantai di Pulau Barangcaddi dan Bonebatang didominasi Makroalga dari jenis Padina australis. Perairan pantai di Pulau Baranglompo ditemukan adanya kodominasi Makroalga dari jenis Eucheuma denticulatum dan Gracilaria coronopifolia. Pantai di Kodingarengkeke didominasi oleh Makroalga dari jenis Chlorodesmis fastigiata. Sedangkan perairan pantai di Pulau Badi ditemukan adanya kodominasi Makroalga dari jenis Padina australis dan Chlorodesmis fastigiata. Makroalgae merupakan produsen utama terpenting di laut dan perairan pesisir serta memiliki peran kunci dalam penyerapan polutan, yang memasuki rantai makanan akuatik dan mengancam kesehatan hewan dan manusia sebagai hasil dari biomagnifikasi [14].

Echinodermata yang ditemukan sebanyak 10 jenis dengan kelimpahan total yang bervariasi antar pantai. Jenis Deadema setosum 


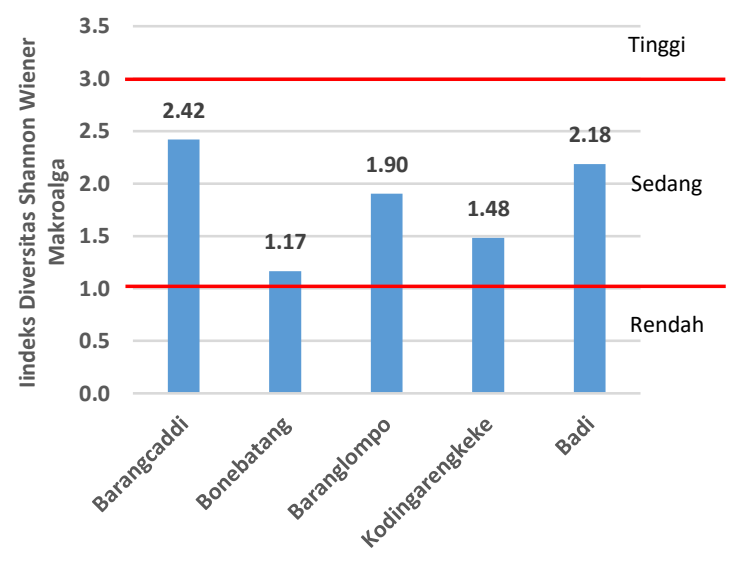

(A)

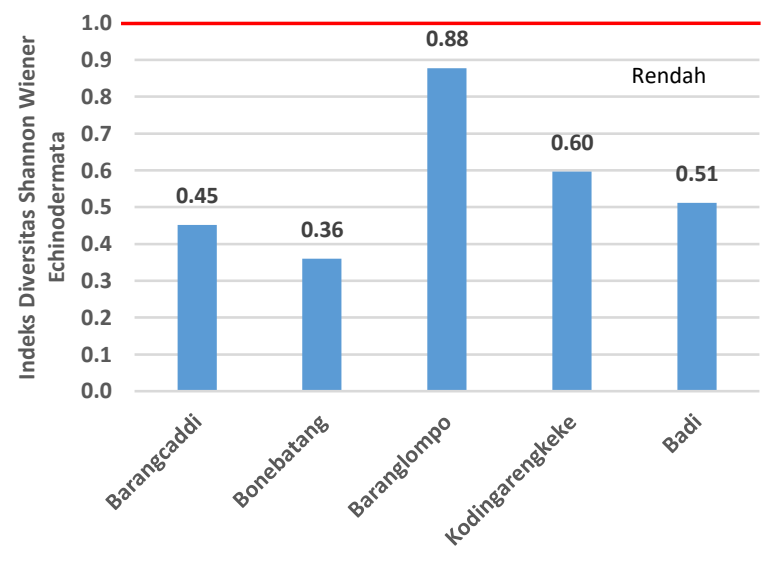

(B)

Gambar 4. Variasi nilai indeks diversitas Shannon-Wiener spesies Makroalga dan Echinodermata di lima pulau Kepulauan Spermonde

selalu mendominasi di semua pantai yang dipantau dengan INP 145-164\%. Jenis Tripneustes gratilla juga ditemukan di semua lokasi dengan INP sedang kecuali di pantai Pulau Badi tidak ditemukan jenis ini. Jenis Ethiotric calamaris ditemukan di tiga lokasi yaitu pantai sekitar Pulau Barangcaddi, Bonebatang dan Kodingarengkeke. Jenis-jenis yang lain menyebar di lokasi tertentu dengan frekuensi yang rendah.

Echinodermata dapat digunakan untuk bioindikator pencemaran suatu perairan. Monitoring polusi limbah bisa dilakukan menggunakan spesies landak laut (Arbacia lixula dan Paracentrotus lividus) di Laut Mediterania melalui analisis fluctuating asymetry (FA) sebagai indikator [15]. Selain itu, akumulasi beberapa logam berat di gonad dan calcified body compartments dari Deadema setosum teramati di gugusan terumbu karang Singapura [16].

Berdasarkan hasil perhitungan indeks diversitas Shannon-Wiener dari komunitas Makroalga (Gambar 4A) ditemukan nilai antara 1,17-2,42 yang menunjukkan tingkat keragaman Makroalga yang sedang. Lokasi dengan kekayaan taksa dan kelimpahan total tertinggi yaitu perairan pantai di Barangcaddi dan Badi, juga mempunyai nilai indeks diversitas yang tinggi pula yaitu 2,42 dan 2,18. Sedangkan tiga perairan pantai yang lain mempunyai indeks diversitas jenis Makroalga lebih rendah yaitu berkisar antara 1,17-1,9. Nilai indeks diversitas Shannon-Wiener Echinodermata (Gambar 4B) termasuk kategori sangat rendah 0,36-0,88 mengindikasikan terjadinya pencemaran di perairan atau habitat yang tidak sesuai untuk pertumbuhan Echinodermata. Hal ini sesuai dengan hasil pengukuran kualitas air pantai ke lima pulau yang menunjukkan tingkat pencemaran bahan organik tinggi ditandai dengan kadar BOD melebihi nilai baku mutu untuk biota air dan juga kadar nitrat yang tinggi pula.

\section{KESIMPULAN}

Aktivitas manusia yang ada di lima pulau Kepulauan Spermonde telah berdampak pada penurunan kualitas air di perairan pantai. Hal ini dicirikan oleh peningkatan tingkat kekeruhan dan bahan organik (BOD) yang selanjutnya dapat memicu terjadinya eutrofikasi tercermin dari kadar nitrat yang telah melebihi baku mutu untuk biota perairan. Pencemaran ini selanjutnya juga berpengaruh terhadap struktur komunitas Makroalga dan Echinodermata. Nilai indeks diversitas Makroalga perairan pantai di sekitar lima pulau yang diamati termasuk rendah sampai sedang, dan nilai indeks diversitas Echinodermata termasuk rendah. Sedangkan parameter kualitas air lain terutama $\mathrm{pH}$, suhu, salinitas, kekeruhan, $\mathrm{TP}, \mathrm{H}_{2} \mathrm{~S}$, minyak dan lemak, dan $\mathrm{Pb}$ telah memenuhi standar kualitas air untuk kebutuhan biota perairan berdasarkan Keputusan Menteri Lingkungan Hidup No. $51 / 2004$.

\section{UCAPAN TERIMAKASIH}

Penelitian ini merupakan sebagian dari hasil penelitian yang dibiayai oleh hibah Penelitian Tesis Magister 2019, oleh karena itu 
diucapkan terimakasih kepada Rektor UB dan Direktorat Riset dan Pengabdian Masyarakat Direktorat Jenderal Penguatan Riset dan Pengembangan Kementerian Riset, Teknologi, dan Pendidikan Tinggi.

\section{DAFTAR PUSTAKA}

[1] Amri K (2012) Sinekologi padang lamun akibat tekanan antropogenik: Studi kasus Pulau Barranglompo dan Bonebatang Kepulauan Spermonde Sulawesi Selatan. Disertasi. Sekolah Pasca Sarjana IPB, Bogor.

[2] Arifin T, Yulius Y, Ismail MFA (2012) Kondisi arus pasang surut di perairan pesisir Kota Makassar, Sulawesi Selatan. Depik 1(3): 183-188.

[3] Jørgensen BB, Richardson K (1996) Eutrophication in coastal marine ecosystems. American Geophysical Union, Washington, $272 \mathrm{pp}$

[4] Reil, LAM, Koster M (2000) Eutrophication of marine waters: Effects on benthic microbial communities. Marine Pollution Bulletin 41(1-6): 255263.

[5] Nkwoji JA, Igbo JK, Adeleye AO, Obienu JA, Tony-Obiagwu MJ (2010) Implication of bioindicators in ecological health: Study of a coastal lagoo, Lagos, Nigeria. Agric. Biol. J. N. Am. 1(14): 683-689.

[6] Garcia-Seoane R, Fernández JA, Villares R, Aboal JR (2018) Use of macroalgae to biomonitor pollutants in coastal waters: Optimization of the methodology. Ecological Indicators 84: 710-726.

[7] Gubelit YI, Kovalchuk NA (2010) Macroalgal blooms and species diversity in the transition zone of the Eastern Gulf of Finland. Hydrobiologia 656: 83-86. doi: 10.1007/s10750-010-0425-2.

[8] Al-Homaidan AA, Al-Ghanayem AA, Alkhalifa AH (2011) Green algae as bioindicators of heavy metal pollution in Wadi Hanifah stream, Riyadh, Saudi Arabia. International Journal of Water
Resources and Arid Environments 1(1): 10-15.

[9] Reinecke SA, Reinecke AJ (2014) Cellular responses of the starfish Parvalustra exigua to metal pollution in False Bay, South Africa. African Zoology 49(2): 233-246.

[10] Haas AF, Smith JE, Thompson M, Deheyn DD (2014) Effects of reduced dissolved oxygen concentrations on physiology and fluorescence of hermatypic corals and benthic algae. PeerJ 2: e235. doi: 10.7717/peerj.235.

[11] Cid A, Prado R, Rioboo C, SuarezBregua P, Herrero C (2012) Use of microalgae as biological indicators of pollution: Looking for new relevant cytotoxicity endpoints. In: Johnsen, M. N. (ed.) Microalgae: Biotechnology, Microbiology and Energy. Nova Science Publishers, New York. pp: 311-323.

[12] Kuffner IB, Paul VJ (2001) Effects of nitrate, phosphate and iron on the growth of macroalgae and benthic cyanobacteria from Cocos Lagoon, Guam. Marine Ecology Progress Series222: 63-72.

[13] Prathep A (2005) Spatial and temporal variations in diversity and percentage cover of macroalgae at Sirinart Marine National Park, Phuket Province, Thailand. Science Asia 31: 225-233.

[14] Conti M, Maria A, Finoia G (2010) Metals in molluscs and algae: A NorthSouth Tyrrhenian Sea baseline. Journal of Hazardous Materials 181: 388-392.

[15] Savriama Y, Stige LC, Gerber S, Perez T, Alibert P, David B (2015) Impact of sewage pollution on two species of sea urchins in the Mediterranean Sea (Cortiou, France): Radial asymmetry as a bioindicator of stress Ecological Indicators 54:39-47. doi: 10.1016/j.ecolind.2015.02.004.

[16] Flammang P, Warnau M, Temara A, Lane DJW, Jangoux M (1997) Heavy metals in Diadema setosum (Echinodermata, Echinoidea) from Singapore coral reefs. Journal of Sea Research 38: 35-45. 